\title{
Society Reports
}

\section{SEGTION OF MEDICAL HISTORY \\ IN THE BRITISH MEDICAL ASSOCIATION \\ (VICTORIAN BRANCH)}

A meeting of the section was held in the Medical Society Hall, 426 Albert Street, East Melbourne, Victoria, Australia, on Monday I 7 March, at 8.15 p.m.

Miss Ann Williams read a paper on Dr. L. L. Smith, a colourful character who practised medicine in Melbourne in the latter part of the nineteenth and the early part of the twentieth century.

Miss Williams began her paper by tracing Dr. Smith's life from his birth in 1830 , through his graduation as Licentiate of the Society of Apothecaries in 1851 , and his arrival in Australia in 1852. This was the era of the gold rush in Victoria, and Smith practised for a time on the goldfields, but later set up practice in Melbourne. Throughout his career he carried out many practices which were quite common in those days, but would not be acceptable in the profession today. He advertised regularly in the press and by every other available means, but made a virtue of this by stating that his advertising was open and that he was not hypocritical about it. He said that the very people who criticized him also advertised, but they did so more subtly by maintaining ostentatious dwellings and carriages, and by keeping themselves well before the public eye at social functions.

He lectured extensively to the public and produced a number of books, pamphlets and journals which he distributed freely. He advertised and sold 'patent' medicines and pills. Politically he was an Independent Liberal with radical views, and was elected to the Victorian Legislative Assembly as Member for South Burke. His hobbies were his model farms and breeding race-horses. In spite of his faults he was a man of remarkable energy and enterprise.

\section{THE SGOTTISH SOGIETY OF THE HISTORY OF MEDICINE}

\section{Thirtieth Meeting and Ninth Annual General Meeting}

THE thirtieth meeting and ninth annual general meeting of the Society was held on 18 October 1957 in the library of the Royal College of Physicians of Edinburgh, Mr. A. L. Goodall, the President, in the chair. The Annual Report of the Society for 1956-7 was presented and unanimously adopted. Mr. Goodall, on his demitting office as President, thanked the Society for its support during his term, and called for nominations for his successor. Dr. W. S. Mitchell, Librarian to King's College Library, Newcastle upon Tyne, was proposed, seconded and unanimously elected. After taking the chair, Dr. Mitchell thanked the Society for the honour conferred on him, remarking that he was the first non-medical occupant of the office of President. He paid tribute to Mr. Goodall and to Dr. John Ritchie, a former President and founder member, who demitted all office in the Society.

Dr. Douglas Guthrie then addressed the meeting, taking as his subject 'Holland and Scotland in Medical Partnership'. Describing how William the Silent was doubtless surprised when, as a reward for the services rendered to him by the people of

$$
306
$$

